\title{
O quixotismo como forma de existência
}

\author{
Quixotism as a form of existence \\ Eunice Prudenciano de Souza \\ Universidade Federal de Mato Grosso do Sul - Mato Grosso do Sul - Brasil
}

$\diamond$

Resumo: O comportamento inaugurado pela narrativa arquetípica de Miguel de Cervantes, Dom Quixote de la Mancha (1605/1615), ecoa em inúmeras narrativas modernas ocidentais. Dentre estas, podemos apontar as performances de dois protagonistas brasileiros: Vitorino, de Fogo Morto (1943), de José Lins do Rego, e Ponciano de Azeredo Furtado, de $O$ coronel e o lobisomem (1964), de José Cândido de Carvalho. O presente estudo parte da narrativa de Cervantes e, por meio dela, estabelece pontos de contato com os romances brasileiros, a fim de verificar em que medida os protagonistas brasileiros retomam o modo de agir - imortalizado sob a concepção de quixotismo - do herói cervantino.

Palavras-chave: Personagem; Ponciano de Azeredo; Quixotismo; Vitorino

\begin{abstract}
The behavior inaugurated by Miguel de Cervantes' archetypal narrative, Don Quixote de la Mancha (1605/1615), echoes in innumerable modern western narratives. Among these, we can point out the performances of two Brazilian protagonists: Vitorino, of Fogo Morto (1943), by José Lins do Rego, and Ponciano de Azeredo Furtado, of $O$ coronel e o lobisomem (1964) by José Cândido de Carvalho. The present study starts from Cervantes' narrative and, through it, establishes contact points with the Brazilian novels, in order to verify to what extent the Brazilian protagonists return to the mode of acting - immortalized under the conception of Quixotism - of the Cervantes' hero.
\end{abstract}

Keywords: Character; Ponciano de Azeredo; Quixotism; Vitorino

\section{Introdução}

Há romances em que o espaço é privilegiado; em outros, é o enredo ou a forma que se sobressai, e há aqueles em que todos os elementos da narrativa estão em função de sua personagem. Dentre estes, há casos em que as personagens crescem a ponto de tomar vida própria, tornando-se, não raras vezes, mais notórias que seu próprio criador, a exemplo de Sherlock Holmes, de Sir Arthur Conan Doyle. Outras imortalizam-se, como o famoso cavaleiro da triste figura, protagonista de Dom Quixote de la Mancha (1605/1615), de Miguel de Cervantes, tornando-se tão conhecidas quanto seu próprio criador.

Para o romance de Cervantes, a assertiva "Character is plot", de Henry James pode ser tomada como ponto de partida para a compreensão do poder que emana da figura de Quixote, responsável pelo desencadear das ações e conflitos da narrativa, sendo que todo o enredo conflui para sua força. Inúmeras obras têm dialogado com Dom Quixote, principalmente em relação à configuração de seu protagonista ou herói. Talvez anti-herói seja o mais apropriado para designar uma personagem sonhadora, frágil, sem beleza, contrário a tudo o que representava a ideia de herói até o momento de sua publicação. A partir de Quixote, mesmo sem revelar os traços enobrecedores dos antigos heróis, o anti-herói não só será posto em cena como poderá tomar o papel de protagonista e seus fracassos e insucessos serão desnudados em toda sua humanidade.

A personagem de Cervantes é responsável pela força e eficácia do romance D. Quixote e, a despeito de suas ações ensandecidas, aceitamos a sua verdade e compactuamos com seus sonhos. Quixote está distante de ser transposição fiel de modelos ou cópia do real, mas nos convencemos de sua existência. A grande questão da arte não está em ser cópia do real, mas convencer o leitor da verossimilhança do texto e isso, com certeza, Dom 
Quixote conseguiu. Prova disso está na confirmação da profecia da personagem de Sansão Carrasco, ao dizer que Dom Quixote ficaria conhecido universalmente e a obra seria traduzida para tantas outras línguas. Hoje sabemos que Dom Quixote é o segundo livro mais editado, perdendo somente para a Bíblia.

Segundo Cândido, em "A personagem de ficção" (2005), a obra literária se realiza quando "um ser fictício, isto é, algo que, sendo uma criação da fantasia, comunica a impressão da mais lídima verdade existencial" (CANDIDO, 2005, p. 55), convencendo, assim, o leitor de sua verdade. Um romance bem realizado prima pelo princípio da verossimilhança e o será na medida em que construir personagens verossímeis, próximas de homens e mulheres do mundo real. Seres complexos, inesperados e intrigantes, acabam por ser mais atraentes e mais convincentes para os leitores, visto que, no mundo real, é praticamente impossível conhecer os seres em toda sua dimensão.

Cândido destaca que a verossimilhança relacionase mais à organização estética do material do que da comparação do mundo ficcional com o mundo real propriamente. Segundo ele, os traços limitados e expressivos da personagem devem se entrosar na composição geral, sugerindo "a totalidade dum modode-ser, duma existência" (Cândido, 2005, p. 75). Dada a impossibilidade de se descrever a totalidade da existência do ser, o ficcionista seleciona os traços para a convencionalização da personagem, tornando-a parte do molde da obra. De modo geral, a convencionalização da personagem advém da "necessidade de adequar as personagens à concepção da obra e às situações que constituem a sua trama." (CÂNDIDO, 2005, p.76). Cândido afirma, ainda, que

a verdade da personagem não depende apenas, nem sobretudo, da relação de origem com a vida, com modelos propostos pela observação, interior ou exterior, direta ou indireta, presente ou passada. Depende, antes de mais nada, da função que exerce na estrutura do romance, de modo a concluirmos que é mais um problema de organização interna que de equivalência à realidade exterior". (CÂNDIDO, 2005, p. 75).

Nesse sentido, podemos pensar que, de um número ilimitado de possíveis elementos caracterizadores de sua conduta, a loucura e o riso - provocados por suas ações exageradas e hiperbólicas - foram os elencados como traços definidores do perfil quixotesco por seu criador. Estes, de igual maneira, podem ser visualizados nas performances dos protagonistas brasileiros, Vitorino, de Fogo Morto (1943), de José Lins do Rego, e do Coronel Ponciano de Azeredo Furtado, de O coronel e o lobisomem
(1964), de José Cândido de Carvalho. O presente estudo parte da narrativa de Cervantes e, por meio dela, estabelece pontos de contato com os romances brasileiros, a fim de verificar em que medida os protagonistas brasileiros retomam o modo de agir - imortalizado sob a concepção de quixotismo - do herói cervantino.

Nossos três protagonistas estão inteiramente ligados com a estrutura interna de cada um dos romances, suas ações, gestões, grandiloquência são representativos do descompasso em relação ao presente vivenciado por cada um, representam seres cindidos entre dois tempos configurados pelas suas respectivas narrativas. São seres tocados pela "loucura da vã presunção", conforme tipologia de Foucault (1999), que corresponderia à relação imaginária que cada personagem estabelece consigo mesma, por meio de um delírio de autovalorização, atribuindo-se características irreais ou, pelo menos, que não estão em consonância com a realidade que as cerca. Por meio desse delírio, criam, ao redor de si, uma redoma que as impede de traçar os limites entre a realidade, a ficção e a loucura, promovendo-lhes constante inquietação, momento em que se acreditam capazes de ajustar o mundo aos seus ideais. A loucura será a forma encontrada, por nossos heróis, para sobreviverem na sociedade degradada que os cerca e, de alguma forma, cada um, ao seu modo, afronta à ordem estabelecida. Suas ações dissonantes, na maior parte das vezes, culminam em situações tragicômicas, provocando o riso.

\section{Quixote e o romance moderno}

Temos em Dom Quixote o modelo do herói problemático, conforme definido por Lukács em Teoria do romance (1933): um indivíduo em conflito com a sociedade. Dessa maneira, na visada cervantina, o herói deixa de representar o coletivo, como na epopeia, para revelar, no romance, sua solidão em um mundo decadente. Para Lukács, há um estreitamento da alma desse herói, que se esforça para realizar-se no mundo exterior, visto estar fechado em um universo de certezas absolutas. Assim, todas as suas ações estão voltadas para a realização de um projeto de vida incompatível com a realidade, provocando sua ruptura com o mundo - elemento determinante para a caracterização dessa tipologia de herói romanesco. Nela o Ideal assume a função de realidade única e o ser vê-se voltado para o desejo da atividade constante; tomado por ideia fixa, seu programa narrativo volta-se então para a ação. Não temos aqui aquele tipo de personagem reflexiva que se perde em longos devaneios.

$\mathrm{O}$ que podemos dizer de um ser que resolve usar a armadura de seus antepassados em suas andanças pelo mundo? Assim como suas ideias estão ultrapassadas, seu traje referencia-se em um tempo que já não existe; 
vestuário este que se coaduna à fala, ao discurso, ao gesto e a tudo mais que a personagem tece para compor a imagem desejada, tal qual aprendera ser usual à performance de um cavaleiro. A cavalaria como forma social, com todos os seus aparatos e rituais, estava definitivamente ultrapassada e, como se sabe, tudo aquilo que está fora de moda, tudo aquilo que não segue normalmente os padrões convencionais torna-se ridículo, cômico, pois, conforme diz Bergson (2007), nesses casos, nossa atenção recai sobre o traje, justamente pela surpresa, pelo contraste com o habitual. A passagem abaixo se refere ao momento em que Quixote decidira levar a cabo tudo o que aprendera nos romances de cavalaria, lidos com tanto afinco e que passaram a povoar sua imaginação incessantemente. São seus primeiros preparativos:

E a primeira cousa que fez foi limpar umas armas que tinham sido dos seus bisavós, e que, desgastadas de ferrugem, jaziam para um canto esquecidas havia séculos. Limpou-as e consertou-as o melhor que pôde; porém viu que tinham uma grande falta, que era não terem celada de encaixe, senão só morrião simples; a isto porém remediou a sua habilidade: arranjou com papelões uma espécie de meia celada, que encaixava com o morrião, representando celada inteira. Verdade é que, para experimentar se lhe saíra forte e poderia com uma cutilada, sacou da espada e lhe atirou duas, e com a primeira para logo desfez o que lhe tinha levado uma semana a arranjar; não deixou de parecer-lhe mal a facilidade com que dera cabo dela, e, para forrar-se a outra que tal, tornou a corregê-la, metendo-lhe por dentro umas barras de ferro, por modo que se deu por satisfeito com a sua fortaleza; e, sem querer aventurarse a mais experiências, a despachou e teve por celada de encaixe das mais finas. (CERVANTES, I, 2005, p. 32).

Dom Quixote vestiu-se com uma armadura velha que pertencera aos seus ancestrais. Queria reformar o presente com as armas do passado e, por isso, fracassa. Seu elmo de Mambrino era fantasioso, na verdade não passava de uma bacia de barbeiro. Mesmo quando Sancho Pança lhe chama atenção para o fato, Quixote responde que cada um vê o que quer ver, basta acreditar. Mesmo desprovido de vestuário adequado, Quixote acredita em seu poder de defender os oprimidos, "é o meu ofício e exercício andar pelo mundo endireitando tortos, e desfazendo agravos" (CERVANTES, I, 2005, p. 158). Ao invés de castelos a defender, dragões e mouros a expulsar, o que Quixote encontra, na região da Mancha, são casebres, albergues, bodegas, cavalos magros; em lugar de lindas e delicadas donzelas depara-se com mulheres sofridas e vulgares. Mesmo assim mantém-se fiel ao seu dever de lutar pelos "injustiçados", saindo em defesa de ladrões, condenados e damas de integridade duvidosa. Encontra pessoas que acabam se divertindo com o despautério das situações nas quais se envolve. Seus inimigos reais são a estrutura política rígida, ricos vassalos, a polícia, a igreja, ou seja, as instituições do poder, que não estão em consonância com seu modo de vida. Dom Quixote é um fidalgo, descende de uma linhagem nobre falida, não concorda com os valores estabelecidos, em que as pessoas não são "iguais" em seus direitos.

Se Quixote fosse somente um cinquentão que enlouqueceu lendo romances de cavalaria, seria provavelmente apenas um ser cômico pelo ridículo da situação, mas, ao construir uma personagem complexa, permeada por ideais nobres, dotada de vasta sabedoria e boas intenções, Cervantes tocou-o pelo sublime e, a partir daí, ele já não será considerado somente um louco que provoca o riso por suas atitudes insanas, mas instigará empatia e identificação por sua extrema bondade e senso de justiça.

A unidade entre o sublime e o cômico na figura de dom Quixote, unidade que nunca mais voltou a ser alcançada, é determinada justamente pela luta genial que Cervantes trava, enquanto cria este caráter, contra as características principais de duas épocas que se sucedem: contra o heroísmo desgastado da cavalaria e contra a baixeza da sociedade burguesa cujo prosaísmo se revela nitidamente desde o início. Esta espécie de 'luta em duas frentes' encerra em si o segredo da grandeza inigualável e se é possível dizer, do realismo fantástico deste primeiro grande romance (LUKÁCS, 1999, p. 100).

Assim, o puramente cômico adentrará ao campo humor, sendo tocado pelo sublime, provocando no leitor admiração e compaixão por um indivíduo tão idealista e ao mesmo tempo tão fragilizado fisicamente.

Vemos Cervantes como um instaurador de discurso à medida que possibilitou uma nova leitura da postura do herói. Essa mudança foi resultado do afastamento do indivíduo das discussões e relações sociais, decorrente das contradições do mundo burguês. O homem moderno, ao contrário do homem do mundo antigo, separa-se das finalidades do grupo e, com o fim da sociedade tribal e o desaparecimento do herói coletivo, o romance, consequentemente, passará a representar a divisão de classes da sociedade moderna.

Para Lukács (1999), “quanto mais o romance se transforma numa representação da sociedade burguesa, em sua crítica e autocrítica criadora, tanto mais claramente nele ressoa o desespero que é provocado no artista pelas contradições, para ele insolúveis, da sociedade em que vive". Dessa forma o herói do romance moderno será o representante de uma única classe em confronto com as demais; a oposição entre o indivíduo e a sociedade seria o 
tema principal dessa nova forma de romance. A sociedade tribal deu lugar ao individualismo da sociedade moderna. Em conformidade, ainda, com Lukács:

Com a desagregação da sociedade tribal, esta forma de representação da ação não pode senão desaparecer da epopeia, uma vez que ela desapareceu da vida da real sociedade. Os caracteres, as ações ou as situações dos indivíduos não podem mais representar toda a sociedade de maneira típica. Cada indivíduo representa apenas uma das classes em luta. E são a profundidade e a validade com que é apreendida uma dada luta de classes em seus aspectos essenciais que definem a essência típica (1933, p.95).

Até o final da Renascença não cabia ao discurso literário expressar o banal, a vida de homens infames, ordinários; tais assuntos ficavam a cargo da fábula, visto que aqueles não podiam servir de exemplo para a máquina do poder. Os que ficavam à margem da sociedade nunca eram postos em cena como seres representativos de modelos de conduta. A partir de Dom Quixote tais personagens não somente serão postos em cena, mas tomados como protagonistas, sem revelar os traços enobrecedores dos antigos heróis. Apesar do anti-herói já ter dado o ar da graça com a novela picaresca, Lazarillo de Tormes (1554), demarcando e ridicularizando as diferenças entre nobres e servos, o anti-herói moderno, com toda sua densidade e suas contradições, iniciará sua trajetória com Dom Quixote. Segundo Dantas (1997, p. 18), se, por um lado, a Ilíada e a Odisséia representam o sentido da vida do homem antigo, por outro, Quixote vem sendo um dos modelos exemplares em que o espírito moderno tem plasmado as contradições entre homem e sociedade.

Para Lukács, Cervantes rompeu com a totalidade do mundo épico, dividindo o mundo em dois: interior e exterior. A partir daí, a totalidade será possível apenas como ideal. A alma do protagonista cervantino é acabada em si mesma, como uma obra de arte ou divindade, e não pode exprimir-se senão por meio de atitudes inadequadas "devido a esse encerramento maníaco em si mesmo" (LUKÁCS, 1933, p. 113); suas ações, consequentemente, não encontram respaldo na sociedade circundante, gerando um conflito interno indissolúvel, "assim o máximo de sentido adquirido pela experiência vivida torna-se o máximo de não-senso: a sublimidade torna-se loucura, monomania" (LUKÁCS, 1993, p. 113).

Dom Quixote enlouquece lendo romances de cavalaria e sai pelo mundo na tentativa de desfazer agravos, lutando pelos injustiçados. Se, como forma social, a Cavalaria estava ultrapassada, foi possível eternizar seu espírito e sua ética na figura de um louco que, apesar de fonte de riso, é modelo de gravidade e virtude em meio à degenerescência de uma época. Em meio a um momento de degradação dos valores da sociedade espanhola, os ideais cavalheirescos surgem como exemplo de comportamento humano para suprir necessidades mais nobres. Conforme podemos notar na passagem em que Quixote discursa sobre os aspectos positivos da Idade de Ouro, o cavaleiro vê o curso da história como um declínio, havendo a urgência de se buscar os valores no passado a fim de superar, desse modo, a baixeza do mundo, despojado, como se encontra, de todas as suas virtudes. No passado, a virtude e a vileza não haviam se misturado ainda, mas nestes "detestáveis séculos" (CERVANTES, I, 2005, p. 92-94), como diz o fidalgo, os valores são outros, assim, a ordem dos cavaleiros se institui como defensora dos necessitados.

Quixote luta por liberdade e honra, deseja afirmar-se como ser humano, com todas as suas contradições, imerso em um meio hierárquico e dogmático. Tomado por ideia fixa, pauta-se pela ação, não percebendo sua falta de consonância com o mundo exterior. A loucura é primordial na configuração de Quixote, sem a qual seria impossível colocá-lo na dimensão modelar de herói. A absoluta crença em si mesmo é a responsável por sua conduta autocentrada:

D. Quixote sem a loucura, que o fez acreditar em si mesmo, poderia ser o personagem da comédia, mas não o herói dramático que a novela oferece como um exemplo, e que aos nossos olhos sintetiza a contribuição de Cervantes para a formação espiritual do homem moderno. (DANTAS, 1997, p. 29).

O quixotismo passou a representar uma conduta de vida, o ideal de transformação do social pelo resgate de valores, isso sem que o indivíduo apresente grandes preocupações com a viabilidade do respectivo projeto nem com os meios de se atingir os objetivos almejados. Assim, deparamo-nos com uma busca desenfreada por valores nobres, baseada na ideia fixa de se manter imune a degenerescência do meio.

\section{Quixotismo em Ponciano}

Tanto Fogo morto (1943) quanto $O$ coronel e o lobisomem (1964) apresentam o processo de decadência dos coronéis, que perdem seu poder e são engolidos pelas forças emergentes da usina e do capitalismo moderno. Suas personagens debatem-se num "equilíbrio instável"; cindidos entre passado e presente, vivem em constante tensão dramática engendrada pelo malogro de suas ações. Nos dois romances, o mito quixotesco aparece simbolizando um ideário de vida alternativo em meio à sociedade decadente. 
A personagem do coronel Ponciano de Azeredo Furtado, totalmente desajustada ao papel de coronel, herda a fortuna do avô sem, no entanto, conseguir manter as riquezas de outrora, pois não tinha preparo para continuar à frente dos negócios. Representa, no plano psicológico e moral, a situação em que, no nível socioeconômico, estão os engenhos de cana-de-açúcar, diante da decadência dessa cultura no processo histórico brasileiro. Ponciano, em suas manias de grandeza, hiperbólico, descamba para o cômico, ridicularizando a figura do coronel anacrônico no âmbito de um contexto socioeconômico brasileiro de transição. Ponciano é o coronel dos pastos que se acredita, ilusoriamente, capaz de desempenhar o papel de negociante no mundo urbano nascente. Ponciano lida muito bem com "o mundo do lobisomem", mas não consegue lidar com o mundo urbano e com os valores do capitalismo. Ponciano é exagerado em sua performance, hiperbólico e, no exagero, provoca o riso. Desse modo, transforma a figura do coronel em uma personagem quixotesca (meio que às avessas se pensarmos que não possui os valores nobres e o idealismo da personagem cervantina). Essa conduta satiriza o poder dos coronéis em decadência pelo incoercível processo de urbanização e capitalização da sociedade brasileira. Transvestido em papel temático inapropriado, para o qual não possui competência, é punido com a ruína e a loucura.

Destacamos abaixo interessantes observações de Candido sobre as personagens de Fogo morto, que podem ser estendidas a Ponciano e até mesmo a Quixote, por situarem-se em tênue linha de desequilíbrio. A despeito da comicidade provocada por suas ações, há constante tensão dramática engendrada em situações conflituosas resultantes do choque com a realidade.

São sempre indivíduos colocados numa linha perigosa, em equilíbrio instável entre o que foram e o que não serão mais, angustiados por essa condição de desequilíbrio que cria tensões dramáticas, ambientes densamente carregados de tragédia, atmosferas opressivas, em que o irremediável anda solto. Os seus heróis são de decadência e de transição, tipos desorganizados pelo choque entre um passado divorciado do futuro (CANDIDO, 1991, p. 392).

Podemos dizer que tanto $O$ coronel e o lobisomem quanto Dom Quixote mostram-nos concepções de tempo em conflito, representativas de valores degradados, e, consequentemente, uma busca da restauração de valores autênticos. Quixote queria restaurar alguns valores que já não conseguia visualizar na Espanha de então, em ampla transformação. A sociedade brasileira passava por uma época de transição socioeconômica, cujos valores, pautados na política patriarcal do coronelismo, eram substituídos pelos novos valores do capitalismo moderno.
Ponciano de Azeredo Furtado, com a herança do avô, torna-se coronel em uma época em que já não havia mais função política para o coronelismo e Dom Quixote, por sua vez, com a leitura adquirida de romances de cavalaria, faz-se cavaleiro numa época em que já não existem cavaleiros. Na personagem do coronel Ponciano, a heroicidade é uma farsa. Na de Dom Quixote, ao contrário, há idealismo. Ponciano não se propõe enfrentar os perigos com a galhardia de um herói. Seu heroísmo é patético, suas convicções são frágeis, ao contrário das rígidas convicções de Dom Quixote. Ponciano utiliza-se de sua patente de coronel e da herança do avô para o gabo do poder. Acredita que sua grande estatura, o vozeirão, a demonstração de coragem são suficientes para fazer-se respeitar. Até mesmo o charuto faz parte de seu desempenho, "serve para espantar o povinho dos empréstimos". Age como se estivesse atuando. Procede conforme os preceitos militares, que diz ter recebido, como forma de demonstrar sua superioridade e poder, quando, na verdade, falta-lhe a coragem para enfrentar as mais diversas situações. Exemplar, nesse sentido, é o episódio da onça pintada em que Ponciano, com medo, tentando evitar o enfrentamento, diz-se impedido de resolvê-lo, pois estava em terras de seu vizinho, o major Badejo dos Santos. E, pelo código de honra militar, não poderia invadir as terras do outro sem denegrir sua patente, como pode ser visualizado na passagem transcrita abaixo:

Pedi calma - e com calma, levantando os dois metros de Ponciano de Azeredo Furtado, falei na melhor situação:

- Só não desagravo a honra da seleta assistência por ser militar e carecer da licença especial advinda de patente superior.

E dentro dessa ponderação, fiz ver que não levava medo de cara enfarruscada. Mas, sendo alferes, não podia, sem penas e agravos, denegrir as leis e regulamentos de guerra (CARVALHO, 2000, p. 13).

Como sou de matar a cobra e mostrar o pau, antes que o marcador de rês caísse em espanto, troquei em miúdo os porquês da medida. Não podia eu, sem deslustrar a patente, levar a guerra aos pastos de Badejo dos Santos, um parceiro de armas, muito capaz de tomar providência como afronta ao seu galão. A pintada, em matas do major, fugia ao meu tiro mortal. Descaí nos pormenores:

- É da pragmática militar, Seu João Ramalho. É dos regulamentos da guerra, seu compadre (CARVALHO, 2000, p. 29).

Ponciano enaltece sua performance e preparo militar. Tece uma autoimagem, como forma de justificar suas ações. Em sua vã presunção, liga seu procedimento aos rituais militares. Acredita que seu poder e honra estarão assegurados pelo simples uso da patente. Para tanto, 
sempre faz questão que seu nome venha acompanhado da patente:

[...] Do meio da desordem saiu meu nome:

- Ponciano! Ponciano!

Não apreciei essas confianças tomadas comigo, sabido por todos que muito prezo a patente e não gosto de ver meu nome solteiro dela, em intimidade que não dou a nenhuns (CARVALHO, 2000, p. 106).

Em suas bravatas, o coronel Ponciano de Azeredo Furtado torna-se uma espécie de herói picaresco da cidade de Campos de Goitacazes. Diante da sua inadequação ao tempo/espaço que o cerca, suas ações tornam-se desprovidas de sentido. Contador de suas façanhas e do esforço para lutar contra as mais variadas formas de injustiça, na tentativa de passar a imagem de pessoa sempre pronta para "o que der e vier", exagera na narração de sua performance e na competência para executá-la; no entanto, é um ingênuo diante das safadezas dos novos tempos, totalmente inapto. Consequentemente, despreparado para questões econômicas e administrativas (especulação do açúcar), não consegue lidar com as transformações dos novos tempos.

Assim, narrador-protagonista, conta-nos o que quer e do jeito preferido: com burlas. Trata-se de uma espécie de cavaleiro andante das causas perdidas, solteirão (como Quixote) e rico. Ao longo das descrições das peripécias do coronel Ponciano, visto que estão sob seu ponto de vista, temos as suas bravatas militares enaltecidas, colocando-o na condição de destemido, porém, com desfechos burlescos. Isso por que o coronel nem sempre age de acordo com a preparação militar que diz ter recebido, fugindo de qualquer enfrentamento real. A veracidade do discurso de Ponciano é relativizada, visto que cabe a ele a seleção e a apresentação dos acontecimentos, recurso que, se por um lado vincula-se à manipulação e ao convencimento, por outro leva à desconfiança diante dos exageros e pouca modéstia do narrador-Ponciano. Essa dupla articulação do papel de Ponciano, narrador e personagem, que ora aproxima-o ora afasta-o dos fatos narrados, possibilita a reflexão do narrador sobre os acontecimentos passados. Ponciano busca sua identidade esfacelada no passado e, por inúmeras vezes, refere-se a si mesmo como "o neto de meu avô", revelando uma identidade perdida, moldada pelo velho patriarca. E, esfacelado entre dois tempos, Ponciano se refaz por meio da fantasia. Necessita do avô como ponto de referência para prender-se a uma conduta ultrapassada, visto que, no presente, não consegue encontrar qualquer compatibilidade com seu meio.

Dom Quixote é o eterno sonhador que cruza terras desconhecidas na tentativa de buscar uma realidade que lhe seja mais adequada, sonhando em endireitar o mundo. Depois de muitas desilusões, num momento de epifania, recobra a razão ao perceber que o mundo por ele idealizado não existe, morrendo por não poder adequar-se a um mundo que não é o seu. $\mathrm{O}$ coronel Ponciano, ao seu modo, herda do avô uma identidade que não é a sua e, consequentemente, não consegue executar, como lhe compete, a função de patriarca. As terras e a patente de coronel de nada lhe valem, pois não é esse seu papel ou, pelo menos, não foi preparado para exercitá-lo. Não reconhece, ou não quer reconhecer, sua inadequação e, quando o reconhecimento finalmente acontece, perde a razão e morre.

Talvez o mal de nossas personagens advenha da crença total, porque "pouco importa aquilo em que se acredita, desde que se não acredite completamente" (RUSSEL, 1965, p.213). A crença total e inabalável, do tipo que não admite contestação, leva à loucura. E, diante do reconhecimento de que suas crenças e verdades, às quais devotaram incondicionalmente suas vidas, são irreais, infundadas, Quixote e Ponciano descambam para morte. Heróis voltados para a ação, esmagados pelo exterior, só lhes restaria a resignação, o que não estaria em consonância com o dinamismo de seus espíritos.

\section{Quixotismo em Vitorino}

Fogo morto, assim como $O$ coronel e o lobisomem, é um romance de grandes personagens. A cor amarelada da pele de Mestre Amaro, assim como o bater raivoso de seu martelo mesclam-se em sua peculiar definição, tornando-se traços inesquecíveis para o leitor. A loucura, elemento comum às obras em questão - e à que estão submetidas boa parte das personagens de Fogo Morto expõe a decadência individual e coletiva à margem da sociedade e do progresso. A tríade em que se divide o romance Fogo morto: protagonizado pelo seleiro José Amaro, o Capitão Vitorino e o Coronel Lula de Holanda são expressões latentes dos conflitos humanos de um nordeste decadente. Essas personagens lidam com os conflitos sociais da realidade que os circunda, e, não estando preparados para conviver com a nova sociedade em transformação, a loucura, a solidão e a segregação aparecem como consequências da total inadaptação. As contradições interiores dessas personagens revelam seres complexos, de grande densidade psicológica.

Vitorino é o cavaleiro do Pilar que luta por justiça num momento em que os valores do coronelismo estão em declínio. Idealista, luta contra tudo e todos por uma sociedade mais igualitária, com menos injustiças sociais. Motivo de chacota, aos poucos, Vitorino vai transformando sua imagem diante do grupo com o qual convive: 
A briga com Antonio Silvino havia enchido os meninos de admiração. Só mesmo homem de muita coragem faria o que o velho fizera! Todos os homens corriam dos cangaceiros, não havia quem ousasse levantar a voz para o dono de tudo. E assim o velho já não era aquele Papa-Rabo que maltratavam impiedosamente. Vivia Vitorino na conversa, nos arrancos de desaforos, contra os homens da terra. (REGO, 1997, p. 232).

Seu comportamento hiperbólico e sua coragem ensandecida terminam por mudar a visão daqueles que o enxergavam somente como um palhaço, um Papa-Rabo, dono de ações exageradas que não podiam ser levadas a sério.

Tratando-se das descrições físicas dos protagonistas, podemos contar com alguns elementos contraditórios, definidores de seus comportamentos. Tanto em Dom Quixote quanto em Vitorino há, por parte da narrativa, uma ênfase em seus traços físicos negativos magros, mal vestidos, montarias ruins -, mas corajosos, crentes em seus ideais; todavia, em Ponciano há valorização de traços físicos positivos - alta estatura, forte, bem vestido, boa montaria -, mas suas ações e convicções são frágeis, talvez por que lhes foram impostas, como herança, pelo avô Simeão. Quixote e Vitorino são definidos com traços físicos negativos, mas possuem firmeza em suas ações. São corajosos, levam a sério as suas verdades.

Vitorino possui parentes poderosos, influentes, porém, em seu desvario, sonha em derrubar a todos, construir um novo governo em que o graúdo não mandasse no miúdo. Seu poder é imaginário, carrega no nome o paradoxo, enquanto diz que muitos andavam atrás dos poderosos como se fossem carneiros, ele é Vitorino Carneiro da Cunha. Apesar de se sentir como se fosse senhor do mundo, Vitorino é como um carneiro, inofensivo.

Os parentes se riam de seus rompantes, de suas franquezas. Eram todos uns ignorantes [...] era melhor ser como ele, homem sem um palmo de terra, mas sabendo que era capaz de viver conforme os seus desejos. Todos tinham medo do governo. Todos iam atrás de José Paulino e de Quinca do Engenho Novo, como se fossem carneiros de rebanho. Não possuía nada e se sentia como se fosse senhor do mundo (REGO, 1997, p. 253).

Vieira (2005) diz que sua configuração quixotesca torna-o diferente dos demais, leva-o a lutar pelos mais fracos. Fazendo de sua palavra sua principal arma, Vitorino passa a rondar os campos sempre montado num cavalo franzino. Porém a grandeza da personagem está justamente na contradição que o perpassa, sua fragilidade física e os delírios são compensados pela densidade moral e pela intenção humanitária. Sua expressividade está justamente na resistência, no sentido de assegurar os princípios humanitários num mundo que parece se perder num redemoinho. Mesmo que não possa transformar a realidade, sua ação alimenta o projeto quixotesco de uma nova sociedade.

Vitorino é o único, dentre nossas personagens, que, pela obstinação, acaba se impondo. Conforme Cândido (1991, p. 396), a força de seu ideal sobrepõe-se à realidade da decadência: "Redimido pela paranóia heróica, o velho Vitorino se eleva lentamente no conceito público". No decorrer da narrativa, vai adquirindo respeito e admiração dos pequenos. Desse modo, "com a obstinação tranqüila e inquebrantável que só os maníacos podem ter" (CÂNDIDO, 1991, p. 396), Vitorino mantém-se vivo porque sua voz dissonante tem força e, apesar de nem sempre ser ouvido, age com convicção, acredita-se capaz de mudar a situação local; reiterando nosso pensamento de que a loucura pode ser uma possibilidade de sobrevivência do homem frente aos seus pares, quando não lhe resta outra forma de lidar com sua inadaptação. Diante do ser em conflito, só há dois caminhos: a loucura ou a morte. Para Quixote e Ponciano, só a morte poderia solucionar sua problemática diante do mundo. São personagens cujas crenças foram perdendo a força à medida que se mostravam totalmente incoerentes com a realidade. E, quando se deu o reconhecimento, o dilaceramento interior em que se encontram não permitiu retorno. Só a morte é possível diante do autorreconhecimento do sujeito de sua incompatibilidade com o meio.

Para Vitorino, o quixotismo tornou-se uma forma de vida. Lutando contra os desmandos locais e transgredindo as leis, Vitorino mantém sua alma ativa. E, a despeito de sua insanidade, é um dos poucos moradores que consegue perceber o que realmente acontece e não aceita ser mandado nem ser privilegiado pelo parentesco com os poderosos do lugar. Sem prender-se ao passado e a pessoa alguma, projeta um futuro de realizações no plano coletivo. Porém, no anseio de agir, muitas vezes a personagem descamba para o exagero, revelando uma mente em delírio. Assim, a loucura é que determina sua relação com o tempo em que vive. Como pontua Candido, Vitorino tem a capacidade de transfigurar a realidade de acordo com seus sentidos:

Ele não teme os parentes ricos nem as suas artimanhas. Investe contra eles a palavrão, taca e punhal, como contra os delegados, oficiais, prefeitos, opressores do seu povo, gigantes e mágicos de Dom Quixote. Para ele não se coloca o problema da decadência em que vive, porque é homem de cabeça quente e vive do ideal. Tem a capacidade transfiguradora de ver aquilo que a imaginação e não os sentidos mandam (CÂNDIDO, 1991, p. 396). 
Em sua insanidade, Vitorino é admirado pela coragem e obstinação com que enfrenta a tudo e a todos. Para ele um homem que luta por seus ideais nunca será desonrado ou considerado inferior, seja o que quer que lhe aconteça, o importante é a voz que não se cala. Assim como Quixote, Vitorino acredita que somente pela honra e pela liberdade se pode e se deve arriscar a vida, sendo fiel às suas crenças. Conforme o narrador:

[...] Vitorino fechou os olhos, mas estava muito bem acordado com os pensamentos voltados para a vida dos outros. [...] Todos necessitavam de Vitorino Carneiro da Cunha. [...] O governo não podia com sua determinação. Ele sabia que havia muitos outros tenentes Maurícios na dependência e às ordens do governo. [...] Mas Vitorino Carneiro da Cunha mandava no que era seu, na sua vida. As feridas que lhe abriam no corpo nada queriam dizer. Não havia força que pudesse com ele. Os parentes se riam de seus rompantes, de suas franquezas. Eram todos uns ignorantes [...] era melhor ser como ele, homem sem um palmo de terra, mas sabendo que era capaz de viver conforme os seus desejos. Todos tinham medo do governo. Todos iam atrás de José Paulino e de Quinca do Engenho Novo, como se fossem carneiros de rebanho. Não possuía nada e se sentia como se fosse senhor do mundo (REGO, 1997, p. 253).

[...] um homem que se preza não deve se entregar [...] - E, Vitorino, mas tu vai sofrer outra desfeita.

- Que desfeita? Um homem que luta não é desfeiteado [...] (REGO, 1997, p. 255).

Em sua paranoia, tomado pela loucura da vã presunção - crença infundada em estar-se tomado por poderes que na realidade não possui - ou ainda por meio de uma autovalorização, como define Candido, Vitorino acredita-se dotado de poderes cada vez maiores. Diante de tanta obstinação, adquire respeito daqueles que só viam nele a figura de um palhaço. Ao final da narrativa, vemos Vitorino vislumbrando um futuro próximo em que ele mesmo seria o governante da cidade. Ficou a imaginar quem seriam seus auxiliares na câmara, a quem entregaria a tesouraria e que, principalmente, em seu governo, o primo Coronel José Paulino seria obrigado a pagar os impostos que nunca pagara: "todos pagariam impostos. Porque José Paulino não queria pagar impostos? Ele próprio iria com os fiscais cobrar os dízimos no Santa Rosa. Queria ver o ricaço espernear" (REGO, 1997, p. 254). No auge de seu delírio, sente-se um vencedor; seria finalmente aclamado pelo povo:

[...] Quando entrasse na Câmara sacudiriam flores em cima dele. Dariam vivas, gritando pelo chefe que tomava a direção do município. Mandaria abrir as portas da cadeia. Todos ficariam contentes com o seu triunfo. A queda de José Paulino seria de estrondo. Ah, com ele não havia grandes mandando em pequenos. Ele de cima quebraria a goga dos parentes que pensavam que a vila fosse bagaceira de engenho. [...] E escorado no portal da casa de taipa, de chão de barro, de paredes pretas, Vitorino era dono do mundo que via, da terra que a lua branqueava, do povo que precisava de sua proteção.

[...]

Depois, com as portas fechadas, [...] continuou a fazer e a desfazer coisas, a comprar, a levantar, a destruir com as suas mãos trêmulas, com o seu coração puro (REGO, 1997, p. 256).

Em sua imaginação ele "continuou a fazer e a desfazer", e tudo estava, finalmente, ao seu alcance. O povo precisava de sua proteção e ele jamais iria abandoná-los, nunca iria para a capital com o filho porque ali era seu lugar, defendendo o povo da roubalheira dos poderosos. Vitorino, com seu coração puro, é um herói louco, "mas com a direta ingenuidade dos puros, que sentem em si a inspiração e querem realmente servir. Com a obstinação tranqüila e inquebrantável que só os maníacos podem ter" (CANDIDO, 1991, p. 396).

Diante da inadaptação, apenas Vitorino triunfa. Dos três protagonistas, Vitorino é o único que apresenta certa mobilidade e tenta se adaptar; consegue encontrar na loucura um modo de sobreviver em meio à sociedade degradante; deixa de ser o "Papa-Rabo" para ser admirado pelo grupo. Acredita-se realmente munido de poderes para regeneração da sociedade. Até o fim vê-se como vítima de perseguição política e, em seu delírio, seu prestígio e poder só tendem a aumentar. Ao final da narrativa, imagina-se governando a cidade e apoiado por grande eleitorado. Em sua vã presunção faz e acontece, começando um período de mudanças.

\section{Considerações finais}

De alguma forma, como aponta Marchezan (2002, p. 44), ao comparar Vitorino e Ponciano, essas personagens "têm no delírio a maneira de se colocarem no centro do mundo". A despeito do homem insano ser aquele tomado em um mundo social real, sancionado negativamente pela sociedade de que faz parte, nossos anti-heróis fazem da insanidade uma maneira de se colocarem no centro do mundo. Calmon (2003, p.60), em leitura da obra de Foucault, destaca que "através da experiência trágica, experiência eminentemente quixotesca, a loucura deixa de ser um mero objeto da ciência para tornar-se um potente critério de avaliação da vida". Assim, podemos pensar na loucura como um posicionamento diante da vida, ou até mesmo como uma forma de resposta aos condicionamentos sociais. A loucura é uma forma de 
evasão da realidade, em que se pode perceber a frágil identidade do ser, fatidicamente abalado com sua não aceitação. Quando Quixote e Ponciano percebem que suas verdades não correspondem às verdades dos demais, sucumbem. Por sua vez, Vitorino faz de sua loucura sua verdade, sua conduta, sem se importar com a verdade do coletivo. É a única maneira em que o homem pode manter sua integridade, construindo sua própria verdade, ficando imune ao olhar julgador do social.

Nossos protagonistas são seres solitários, sem qualquer ligação com a realidade. Fazem de seu projeto sua vida e não desistem por nada. "Eis um dos principais aspectos do quixotismo: a solidão na luta. [...] ele luta sozinho contra quantos e quais forem os inimigos, gente ou gigantes, encantadores ou exércitos" (BERNARDO, 2006, p. 71). Não possuem qualquer ligação interior com a vida coletiva da comunidade; estão, primeiramente, voltados para a realização de seus objetivos pessoais, que norteiam suas ações. Essas personagens desestabilizamse psicologicamente na medida em que não conseguem lidar com o presente. O seu tempo, assim, transparece ligado à falibilidade do indivíduo, que vê o progresso desestabilizar sua situação de vida sem que tenha tempo de se adequar, afastando-se progressivamente do contato produtivo com o seu mundo. Tais personagens encontramse marcadas pelo anacronismo e pela decadência, num processo irreversível.

O elemento espacial será de grande importância para o desenvolvimento dos percursos narrativos de Ponciano, Quixote e Vitorino. Pode-se dizer que a viagem, as andanças das personagens, é que estabelece a ação, encaminhando cada qual para seu destino trágico. Dom Quixote sai, por três vezes, de sua fazenda, em busca de aventuras, pela defesa dos fracos e oprimidos pelo sistema.

De igual maneira, Ponciano vai para a cidade por duas vezes, deixando a fazenda, o lugar onde sempre vivera. Quando o coronel muda-se para a cidade e passa a viver em meio à "demanda de Foro", "prática de safadeza", situações para as quais não está preparado, tem a sua ruína anunciada, pois passa a viver em um espaço que não é mais o centro de onde emana seu poder. Suas façanhas estão localizadas nos pastos, mas vai para a cidade na tentativa de desvencilhar-se da identidade recebida do avô; prova disso é que, durante o tempo em que fica na cidade não ocupa a casa da Rua da Jaca, herança do avô, onde passara sua infância. Na cidade, ele é o estranho, é enganado por homens e mulheres, que acabam por dilapidar sua fortuna. Próximo à ruína, o último dos Azeredo Furtado volta desiludido para o campo, onde enlouquece e morre.

Vitorino é o "eterno cavaleiro andante", sempre em ação. Munido de uma montaria, que por várias vezes o derruba, vive em busca de uma causa a defender. Toma partido de "grandes", como o coronel Lula de Holanda, na ocasião em que a casa deste foi invadida pelo cangaceiro Antônio Silvino. Mas também defende, com o mesmo fervor, "pequenos", como mestre Amaro, Passarinho e o cego Torquato, quando estes são presos violentamente pela polícia do governo que persegue o cangaceiro Antônio Silvino. Acredita-se superior e algumas vezes até mesmo chega a agir com certo preconceito em relação aos "pequenos".

A viagem proporciona novas vivências ao indivíduo, o que, muitas vezes, pode acarretar uma profunda mudança no modo de ser e de agir de cada um. De certa maneira, podemos mesmo dizer que todo aquele que viaja volta transformado pela experiência vivida. Em suas andanças, impulsionados pelo sonho, pelo desejo de ação no mundo, Dom Quixote passa da loucura para a "lucidez", ao perceber o quão impossível se tornara a sua conduta; e Ponciano, da razão para a loucura, ao perceber sua total incompatibilidade com seus pares. Nesse momento seria adequada uma fala da sobrinha de D. Quixote, a respeito de suas andanças, que, na verdade, cai bem aos protagonistas em questão: "não estaria melhor estar-se manso e pacífico em sua casa, em vez de ir pelo mundo procurar pão fino, sem se lembrar de que muitos vão buscar lã e vêm tosquiados?" (CERVANTES, I, 2005, p. 69). Suas viagens, suas saídas ligam-se às suas decadências e finalmente à ruína desses loucos, excêntricos.

A figura de Dom Quixote tornou-se um símbolo do homem moderno em suas lutas contra as investidas de uma realidade decadente, de uma realidade que não condiz com os sonhos individuais. Trata-se de uma obra triste, a despeito do riso que por vezes possa provocar assim como os romances brasileiros em questão. Advém de uma profunda reflexão sobre os valores decadentes da sociedade seiscentista, de um cavaleiro de mais de cinquenta anos que aprendera muito com suas andanças e também se desencantara, mas extremamente consciente e "lúcido" dentro de sua própria lógica. Como afirma Watt (1997, p.77), por mais insensato que seja o senso militar e político de Quixote, não podemos deixar de reconhecer que "há uma irrefutável lógica imaginativa em sua ideia. Se o mundo atual vive em uma situação de degenerescência, então é claro que temos de recuperar todos os valores do passado". Discursa muito bem Quixote, avaliando cada coisa a seu tempo, com desmedida sabedoria de vida.

A personagem de Cervantes é responsável pela força e eficácia do romance D. Quixote de la Mancha e, a despeito de suas ações ensandecidas, aceitamos a sua verdade e compactuamos com seus sonhos. Quixote está distante de ser transposição fiel de modelos ou cópia do real, mas nos convencemos de sua existência. Talvez por que todos tenhamos um pouco de Quixote, aquela estranha mania de estar sempre em busca dos sonhos e da 
completude. A constância na busca faz parte da existência humana.

À primeira vista, os romances analisados dão-nos a impressão de tratar da trajetória mal sucedida de seus protagonistas doidivanas. Entretanto, num olhar mais atento, percebemos a profundidade psicológica desses heróis inadaptados aos seus respectivos sistemas ideológico-sociais. Estamos lidando com personagens densas, nada se sobrepõem a elas, tamanhas suas grandezas. E estão, de tal modo, permeadas de extraordinária humanidade que enxergamos um pouco de cada um de nós em sua ações.

\section{Referências}

BERGSON, H. O riso: Ensaio sobre a significação da comicidade. Tradução Ivone Castilho Benedetti. São Paulo: Martins Fontes, 2007.

BERNARDO, Gustavo. Verdades quixotescas. São Paulo: Annablume, 2006.

CALMON, Jean. O Dom Quixote de Foucault. Rio de Janeiro: E-papers, 2003.

CÂNDIDO, Antônio. A personagem do romance. In: Cândido, Antônio et al. A personagem de Ficção. 11. ed. São Paulo: Perspectiva, 2005.

CANDIDO, Antonio. Um romancista da decadência. In: COUTINHO, E.; CASTRO, A. B. de. José Lins do Rego. Rio de Janeiro: Civilização Brasileira, João Pessoa: FUNESC, 1991.

CARVALHO, José C. O Coronel e o Lobisomem. Rio de Janeiro: Rocco, 2000.
CERVANTES, Miguel. Dom Quixote de la Mancha. Tradução Viscondes de Castilho e Azevedo. Porto Alegre: L\&PM Pocket, 2005. $2 \mathrm{v}$.

DANTAS, San Tiago. D. Quixote: um apólogo na alma ocidental. Brasília: Universidade de Brasília, 1997.

FOUCAULT, Michel. História da Loucura. Tradução José Teixeira Coelho Neto. São Paulo: Perspectiva, 1999.

LUKÁCS, Georg. Teoria do Romance. Tradução Alfredo Margarido. Lisboa: Presença, 1962.

LUKÁCS, Georg. O romance como epopeia burguesa. In: Revista Ensaios Ad Hominem, t. II, n. 1, 1999. (Tradução Letizia Zini Antunes. São Paulo: Estudos e Ed. Ad Hominem).

MARCHEZAN, Luiz Gonzaga. Fogo Morto e $O$ coronel e o lobisomem: Duas vertentes de uma poética da loucura na literatura brasileira. In: MARCHEZAN, Luiz Gonzaga; TELAROLLI, Sylvia (Org.). Cenas Literárias. Araraquara: Laboratório Editorial, UNESP/FCL; São Paulo: Cultura Acadêmica, 2002.

REGO, José Lins do. Fogo Morto. São Paulo: Klick, 1997.

RUSSEL, Bertrand. Realidade e Ficção. Tradução António Neves Pedro. Lisboa: Europa-América, 1965.

VIEIRA, Maria Augusta da Costa. Em torno da recepção do Quixote no Brasil: escritura cervantina e mito quixotesco. In: TROUCHE, A.; REIS, O. (Org.). Dom Quixote: Utopias. Niterói, RJ: EdUFF, 2005.

WATT, Ian. Mitos do Individualismo Moderno. Tradução Mário Pontes. Rio de Janeiro: Zahar Editor, 1997.

Recebido: $17 / 12 / 2016$

Aprovado: 19/03/2017

Contato: euniceprus@gmail.com 